УДК 81 '272

DOI: $10.24144 / 2617-3921.2019 .17 .76-88$

Ірина Міщинська

кандидат педагогічних наук, дочент, дочент кафедри перекладу Хмельнииької Національної академії Державної прикордонної служби

України імені Богдана Хмельницького orcid.org/0000-0002-5232-4811

м. Хмельницький, Україна, 0931533032, mischynska@ukr.net

\title{
Мовленнєві ситуації англомовного ділового дискурсу
}

Анотація. У статті здійснено аналіз мовленнєвих ситуаиій як одиниць комунікативної компетенції, розглянуті ознаки мовленнєвих ситуацій. Проаналізовані підходи до ділового дискурсу в науковій літературі. Визначені особливості ділового дискурсу з точки зору дискурсивного аналізу. Наведено 
характеристику мовленнєвих ситуацій англомовного ділового дискурсу. Визначені мовні засоби, які є ефективними в створенні когнітивних образів, які сприяють досягненню комунікативної мети мовленнєвих ситуацій, а саме: професійна термінологія, професійний жаргон, професійний сленг, застосуванням кліше, метафор в різних видах текстів.

Ключові слова: комунікативна компетенція, економічний дискурс, бізнес-дискурс, професійна термінологія, мовні засоби, професійний жаргон.

Abstract. The article presents the analysis of communicative situations as units of communicative competence. Main features of communicative situations are highlighted in the article. Academic approaches to business discourse are analyzed. Peculiarities of business discourse are determined in view of discourse analysis. The author defines characteristic traits of communicative situations of business discourse. It is stated that communicative situations of business discourse refer either to economic discourse or to business discourse. Communicative situations are intentional. Communicative goals of communicative situations are achieved due to creating cognitive images in the process of communication. It is defined that certain language means are used to achieve these goals. Such language means as professional terms, professional jargon, slang, clichés, metaphors in various types of texts are used in English business discourse.

Keywords: communicative competence, economic discourse, business discourse, language means, professional terms, professional jargon.

Вступ. Діловий дискурс, представлений економічним дискурсом та бізнес-дискурсом, переконливо охоплює сфери соціальної та економічної діяльності людини як наслідок розвитку постіндустріального суспільства в епоху глобалізації. Розширення сфер економічного співробітництва та ведення бізнесу в різних галузях вимагають комунікації як в усній, так і в письмовій формі, внаслідок чого широко застосовується термінологія ділового мовлення, виробляються стандартні зразки комунікації, представлені в комунікативних ситуаціях. Необхідність визначення особливостей мовленнєвих ситуацій, які утворюють динаміку ділового дискурсу в усіх сферах діяльності в умовах міжнародного співробітництва, зумовлює актуальність обраної теми.

B. I. Карасик розглядає дискурс як “семіотичний простір, який складається 3 вербальних i невербальних знаків, орієнтованих на обслуговування певної комунікативної сфери, а також тезаурус прецедентних висловлень і текстів" [4, с. 132]. Уявлення про дискурс тісно пов'язано 3 моделями мовленнєвої поведінки та набором мовленнєвих дій і жанрів, специфічних для певного типу комунікації [12, с. 11].

При цьому особистісно-орієнтований та статусно-орієнтований типи дискурсу знаходяться в опозиції. На думку В. Карасика, у першому випадку нас цікавить адресант з усіма його особистісними характеристиками, у 
другому - також адресант, але вже як представник тієї чи іншої групи людей. "Особистісно-орієнтований дискурс представлений у двох основних різновидах - побутовому й художньому спілкуванні; статусно-орієнтований дискурс - у багатьох різновидах, що виділяються в тому або іншому суспільстві згідно прийнятих у ньому сфер спілкування та існуючих суспільних інститутів (політичного, ділового, наукового, педагогічного, медичного, військового, спортивного, релігійного, юридичного та ін.)" [3,с. 4].

За соціально-ситуативним параметром розрізняють політичний, адміністративний, юридичний, військовий, релігійний, медичний, діловий, рекламний, педагогічний, спортивний, науковий, електронний (інтернетдискурс), медійний (засобів масової інформації) типи дискурсу тощо [11, с. 233-236].

Типи дискурсу тісно пов'язані 3 мовленнєвими жанрами, які реалізуються в певних комунікативних ситуаціях. Заслуговують на увагу дослідження комунікативних ситуацій в межах мовленнєвих жанрів, які здійснювали мовознавці Ф. С. Бацевич, В. І. Бєліков, І. Н. Борисова, І. В. Шерстяних, І. Р. Корольова, В. В. Красних, Л. П. Крисін, А. Ю. Маслова, К. Ф. Сєдов, С. Є. Устименко, Н. І. Формановська та ін.

Дослідження різних аспектів англомовного дискурсу проводилися науковцями Дж. Габермасом, Дж. Голмсом, Дж. Серлем та іншими лінгвістами. Ф. Баргіела-Чаппіні та К. Нікерсон, Е. Гофман, Т. Дадлі-Еванс та М. Дж. Сент Джон та інші розглядали особливості ділового дискурсу. Однак питання мовленнєвих ситуацій англомовного ділового дискурсу недостатньо висвітлені у вітчизняній науковій літературі, що й зумовило необхідність їх дослідження.

Мета дослідження - визначення особливостей мовленнєвих або комунікативних ситуацій, які розвиваються в процесі англомовного ділового дискурсу. Відповідно до мети дослідження визначені такі завдання:

1. Аналіз мовленнєвих ситуацій як одиниць комунікативної компетенції;

2. Визначення особливостей ділового дискурсу з точки зору дискурсивного аналізу;

3. Характеристика мовленнєвих ситуацій англомовного ділового дискурсу.

Методологія та методи дослідження. Матеріалом дослідження слугували фрагменти мікродіалогів та інформаційних повідомлень представників бізнесу в різних комунікативних ситуаціях фахового спілкування, виокремлених методом суцільної вибірки із текстів ділової документації, представленої текстами корпоративного дискурсу та текстами прес-релізів компанії McLaren. У дослідженні використовувалися методи теоретичного узагальнення та зіставного аналізу. Теоретичне узагальнення проводилося на основі аналізу робіт вітчизняних та іноземних науковців, в яких розглядалися особливості комунікативних ситуацій. Зіставний аналіз 
поглядів різних науковців дозволив виявити основні тенденції розвитку комунікативних ситуацій англомовного ділового дискурсу в різних сферах діяльності. Для вивчення особливостей комунікативних ситуацій в англомовному діловому дискурсі було застосовано метод дискурс-аналізу. Виявлення комунікативних намірів адресата здійснювалося за допомогою методу інтент-аналізу.

\section{Виклад основного матеріалу дослідження.}

Поняття мовленнєвих ситуацій нерозривно пов'язане з комунікативною компетенцією, яка передбачає не лише знання мовного коду, а й усвідомлення того, що кому говориться і як сказати це відповідно до конкретної ситуації. Отже, необхідна наявність певних “соціальних i культурних знать у комунікантів, які допомагають їм застосовувати й інтерпретувати лінгвістичні форми. Комунікативна компетенція поширюється на усвідомлення того, хто може і хто не може говорити в певних ситуаціях, до кого можна звертатися, як можна розмовляти з особами певного статусу й ролі, яка невербальна поведінка $\epsilon$ прийнятною в різноманітних контекстах, яка черговість спостерігається в розмовах, як надавати запит про інформацію і як іiї повідомляти, як виголосити вимогу, як вносити пропозиції про допомогу чи співпрацю, як віддавати команди, як посилити дисципліну тощо - всього, що вимагає застосування мови та інших комунікативних модальностей в певному соціальному оточенні” [20, с. 18].

Одиницями аналізу комунікативної компетенції, запропонованими Д. Хаймсом, вважаються мовленнєві ситуації, мовленнєві події, мовленнєві акти [9]. Комунікативна ситуація є тим контекстом, в якому відбувається власне комунікація. Прикладами комунікативних ситуацій можуть слугувати судове засідання, аукціон, святкова вечірка, наукова конференція тощо. Мовленнєва ситуація залишиться незмінною навіть за умови зміни місця іiі проведення: процедура мовленнєвої ситуації буде витримана, хоча взаємодія комунікантів може бути урізноманітнена, що знаходить відображення в мовленнєвих актах.

Комунікативна ситуація трактується В. Ущиною як “обмежений у часі й просторі цілісний, соціально осмислений процес безпосередньої мовленнєвої взаємодії комунікантів в умовах, якими визначається їхня дискурсивна поведінка і способи реалізації їхніх прагмакомунікативних інтенцій” (93). Ознаками мовленнєвої ситуації вважаються: 1) місце спілкування; 2) учасники спілкування (їхні особистісні властивості й характер взаємин один 3 одним); 3) мотив спілкування; 4) мовленнєвий намір; 5) сфера спілкування; 6) тема спілкування (Авронин 5).

Мовленнєва/ комунікативна ситуація включає певну кількість мовленнєвих подій. Наприклад, мовленнєва ситуація судового засідання передбачає такі події, як відкриття судового засідання, виголошення справи проти обвинувачуваного, визнання обвинувачуваного себе винним/ невинним, винесення йому вироку у разі визнання себе винним або власне 
судового процесу в разі його невизнання себе винним, що включає окремий перелік мовленнєвих подій, нарешті, винесення вироку 3 наступним визначенням міри покарання у разі доведення вини підсудного. Кожна комунікативна подія складається 3 визначеного переліку компонентів, об'єднаних спільною метою комунікації, в яких задіяні ті самі учасники. При цьому комуніканти дотримуються визначених процедурою даної ситуації правил у спілкуванні, застосовуючи той самий різновид мови.

Комунікативні акти, 3 яких складаються комунікативні події, які виконують одиничні інтерактивні функції, такі як твердження, вимоги чи команди, також можуть бути вербальними та невербальними.

Згідно $з$ теорією Дж. Серля [21, с.23-24], ми здійснюємо різні мовленнєві акти в процесі розмови, застосовуючи різноманітні висловлювання. Більшість цих висловлювань виражають певний намір мовця. Вони називаються ілокутивними актами і мають певну ілокутивну силу. Мовець може також застосовувати різні висловлювання для досягнення однакового ілокутивного ефекту або застосовувати одне й те саме висловлювання для досягнення різних цілей.

Як стверджує Дж. Серль, ілокутивні акти повинні здійснюватися “намірено” [21,c.145-146]. Дж. Серль також уточнює п'ять категорій перформативів, запропонованих лінгвістом Дж. Л. Остіном (в дужках), визначаючи їхній намір, а саме: асертиви (експозитиви), які переконують співбесідника у вірності твердження; директиви (вердиктиви), які переконують співбесідника таким чином, щоб його поведінка відповідала пропозиційному змісту висловлювання; комісиви (комісиви), які спонукають співбесідника здійснити дії відповідно до пропозиційного контенту висловлювання; експресиви (біхебітиви), що виражають щирість висловлюваного; декларативи (екзерситиви), що виявляють певну зміну у навколишному середовищі, представляючи його зміненим [21,с. 12-20].

На противагу Дж. Л. Остіну, який зосереджує увагу на тому як мовці реалізують свої наміри в мовленні, Дж. Серль звертає свою увагу на те як співбесідники сприймають висловлені звернення, тобто в який спосіб одна особа намагається визначити як інша особа використовує певне висловлювання. Чи є почуте обіцянкою, застереженням, ствердженням, вимогою чи ще чимось? Якою $\epsilon$ ілокутивна спрямованість певного висловлювання?

Вважається, що мовленнєві акти можуть бути експресивними в суб'єктивному світі (відображати особу мовця), інтерактивними в соціальному світі (відображати особу співрозмовника) або дескриптивними в об'єктивному світі (відображати третіх осіб) (Habermas). В цих трьох моделях наголошується на тому, що кожний тип мовленнєвого акту в мові менеджменту передбачає свої власні норми щирості, правоти й правдоподібності. 
Ще одна відмінність, на яку слід зважати, це відмінність між “живим словом" і “системою” (наприклад, фінансовим чи політичним закладом). Під “живим словом” Дж. Габермас розуміє наш "запас безумовних культурних даних, 3 яких учасники комунікації отримують узгоджені зразки інтерпретації” [18, с.135]. На думку Дж. Габермаса, це - “культурний запас знань, який є “завжди заздалегідь” відомим” [18, с.125]. Через це він виступає не стільки в якості потенційного об'єкта інтерпретації, якими є суб'єктивний, інтер-суб'єктивний та об'єктивний світи, скільки в якості посередника, в якому менеджери прагнуть зрозуміти якийсь аспект цих світів, що $\epsilon$ проблематичним.

Формами ділової комунікації в діловому світі вважаються: комунікація на основі інтернет-зв'язку, яка може здійснюватися незалежно від часу й місця; комунікація у формі відео-конференцій; комунікація у формі повідомлень електронної пошти; доповіді по роботі різноманітних відділів; презентації, які є надзвичайно популярною формою комунікації, що включає аудіо- та відеоматеріали, копії доповідей чи матеріали, підготовлені у форматі Microsoft PowerPoint або Adobe Flash; телефонні розмови, які дозволяють здійснювати комунікацію на дистанції; дошки оголошень, що дозволяє одразу ж зробити інформацію загальнодоступною; особисті зустрічі, які підкріпляються документами в письмовому вигляді.

3 точки зору дискурсивного аналізу при розгляді лексичних та текстових відмінностей між економічним дискурсом та бізнес-дискурсом, можна помітити певний зв'язок між цими видами дискурсу. При цьому бізнес-дискурс можна розглядати як професійно-орієнтовану мову, а економічний дискурс - як академічний код. В академічному дискурсі визначається, що “бізнес в реальному житті - це еквівалент теоретичної економіки" [16,с. 43], що й обумовлює взаємодію між ними. В свою чергу, ділова англійська мова поповнює академічну мову економіки. Ділова англійська мова розвивається в професійні мови - англійську мову комерції та фінансів, які втілюють на практиці теорії, вироблені економічною наукою [16,c.44]. Отже, дві професійні мови комерції та фінансів розвиваються на тлі англійської мови економіки - наукової та академічної мови.

Інтелектуальний суспільно-економічний дискурс, відбуваючись серед нефахівців, наближений до повсякденної форми економіки - тобто бізнесу. Завданням цього дискурсу є донесення академічних знань до певних груп населення зрозумілою мовою. Отже, ця форма дискурсу $\epsilon$ швидше суспільною, ніж академічною чи науковою.

Економічний дискурс розглядається лінгвістами як академічний код чи мова науки. Вважається, що дослідження англійської мови економіки відбувається на основі підручників - абстрактної мови і застосуванні метафор в описі економічних моделей і теорій $[15, c .50]$. Бізнес-дискурс як професійно-орієнтована мова, послуговуючись визначенням Ф. БаргіелаЧаппіні та К. Нікерсон, - це “процес розмов і переписки між особами, 
головна діяльність котрих - сфера бізнесу, і котрі об'єднуються з метою заняття бізнесом" [13, с. 2]. Згідно 3 іншим визначенням тих самих науковців, бізнес-дискурс - це "все про те, як люди спілкуються в усній та письмовій формі в комерційних організаціях 3 метою виконання своєї роботи" [14,с. 3].

Виходячи 3 наведених положень ділового дискурсу, можна стверджувати, що місце мовленнєвих ситуацій ділового дискурсу визначається сферою діяльності комунікантів та способом комунікації: особистої чи опосередкованої засобами комунікації (інтернет, листування звичайною чи електронною поштою, засоби масової інформації тощо). Учасниками мовленнєвих ситуацій в межах цього дискурсу є представники бізнесу, економісти, які займаються питаннями бізнесу й економіки на своєму професійному рівні, представники академічних кіл, які займаються викладанням економічних дисциплін, а також представники засобів масової інформації, які займаються висвітленням питань економіки й бізнесу. Крім того, учасниками цих мовленнєвих ситуацій можуть ставати й пересічні громадяни, якщо їх інтереси дотичні до зазначених сфер людської діяльності. Мотиви спілкування та мовленнєві наміри комунікантів є визначальними факторами в доборі мовних засобів для досягнення комунікативної мети. Причому оскільки будь-яка особа зазвичай належить до більш ніж однієї групи одночасно, мова, якою користуються комуніканти, є відображенням соціальних реалій та досвіду, характерних для всіх груп.

3 хорошої розмови можна зрозуміти як текст, так і контекст (тобто інформацію та її значення). Розуміння правил «мовленнєвої гри» невіддільно пов'язане з поняттям контексту. Детальне вивчення безмежного різноманіття доступних і недоступних безпосередньому спостереженню видів контексту призводить до висновку про його системну природу [6,c.172], яку можна представити у вигляді ієрархії:

- мікроконтекст - міжособистісний, що характеризує мовця як мовну особистість, яка реалізує свою комунікативну інтенцію в певному комунікативному епізоді;

- макроконтекст - більш широкий соціокультурний контекст, що характеризує мовця як представника свого соціуму і своєї культури (субкультури);

- метаконтекст - контекст знання, що характеризує концептуальну систему, в межах якої мислить мовець і яка відображає бачення світу, притаманне даному соціуму.

Метамова бізнесу $є$ самодостатнім лінгвістичним феноменом, свідченням чого є сформованість простору референції, концептуального, інтенційного та стильового просторів. Складовою системи цієї метамови $\epsilon$ соціолекти, хоча їх функціонування обмежено сферою застосування.

Референція - це частина дійсності, співвіднесена зі сферою бізнесу, обмежена спеціальною тематикою та відповідними їй мовленнєвими 
ситуаціями. Простір референції визначається такими процесами в сфері бізнесу, як стратегія бізнесу, фінанси, менеджмент, маркетинг і техніка продажу, логістика, управління персоналом, зв'язки з громадськістю.

Концептуальний простір метамови бізнесу охоплює концепти та поняття ділового мовлення. Серед концептів головними є бізнес, товар, менеджмент а також концепти основних бізнес-процесів стратегія, фінанси, маркетинг, логістика, персонал, PR (зв'язки з громадськістю), які корелюють 3 тематичними полями референції і створюють відповідні семантичні поля.

Інтенційний простір сформований інтенціями - намірами співбесідників, які дозволяють забезпечити ділову комунікацію. Дослідниця Н. I. Формановська визначила основні інтенції, що визначають походження мовленнєвих актів, а саме: інформування, волевияв, спонукання, зобов'язання, вияв емоцій, запит інформації, встановлення контакту [8,с.78]. Зазначені інтенції певною мірою відповідають типам ілокутивних актів, запропонованих Дж. Серлем: інтенції волевияву - декларативам, спонукання директивам, зобов'язання - комісивам, вияву емоцій - експресивам тощо.

Стильовий простір ділового мовлення визначається як сферою ведення бізнес-дискурсу, так і специфікою текстів, які в цій сфері застосовуються. На думку Ю. Н. Караулова, “дискурс - це складне комунікативне явище, яке включає, окрім власне лінгвальних (тексту), екстралінгвальні фактори (знання про світ, настанови, цілі адресата), необхідні для розуміння тексту" $[5, \mathrm{c} .8]$.

Текст при цьому виступає основною одиницею комунікації. Заслуговує на увагу точка зору Т. М. Дрідзе, яка розглядає текст як “цілісну комунікативну одиницю, як... систему комунікативно-пізнавальних елементів, функіонально поєднаних в єдину замкнену ієрархічну змістовносмислову структуру (ісрархію комунікативно-пізнавальних програм) спільною концепцією чи задумом (комунікативним наміром) партнерів по спілкуванню" [2,c.149]. Отже розгляд комунікативних ситуацій ділового дискурсу тісно пов'язаний 3 текстовими матеріалами - діловою документацію, текстами доповідей, презентацій, прес-релізів, телефонних розмов, обговорень, електронної пошти, аудіо- та відеоконференцій, інтерв'ю тощо.

Одним із видів ділового дискурсу $\epsilon$ корпоративний дискурс, за допомогою якого відбувається комунікація між корпорацією та іiі персоналом, починаючи з оголошення про вакансії та інтерв'ю і закінчуючи розпорядженнями й семінарами офіційного введення у виробничий процес. Тексти корпоративного дискурсу представлені документами, що підтверджують i закріплюють членство у корпоративному середовищі; директивами; інструкціями; рекламними матеріалами; повідомленнями електронної пошти; контрактами та юридичними угодами. 
Характеристиками документів, які підтверджують i закріплюють членство у корпоративному середовищі, $є$ формальний словниковий склад i прості граматичні структури, відсутність складних підрядних речень. Стиль цих документів характеризується емоційністю і вишуканою естетичною формою.

Хоча директиви подібні до попереднього розряду документів, оскільки чітко поділяються на підрозділи, однак, вони зазвичай коротші й більш стримані. Їх головна функція - інформативна. Вони $є$ конфіденційними документами, призначеними для службовців і не повинні бути представлені третій стороні. Їм притаманні прості граматичні структури і вокабуляр. Перевага надається наказовому способу.

Інструкції призначені для доведення до робітників інформації про їх поведінку згідно із стратегією компанії та попередження у випадку нанесення ними збитків компанії. За формою вони подібні до директив. Параграфи інструкцій чітко структуровані згідно з таким порядком: загальна інформація, мета, заходи, звітність/ розподіл відповідальності, розділ стосовно предмета укладання документа й список документів, які мають до нього відношення. Залежно від предмету розгляду структура директив може змінюватися.

Рекламні матеріали представлені листівками, брошурами, матеріалами журналів, тощо. Рекламні матеріали зазвичай містять логотип компанії та рекламний лозунг. Оскільки метою рекламних матеріалів $є$ привабити споживача, у них використовується простий лексичний матеріал, добре відомі граматичні конструкції. Текст зазвичай носить характер поради, щоб посилити теплу дружню атмосферу.

Ступінь формальності повідомлень електронної пошти визначається посадами відправника й отримувача. У повідомленнях електронної пошти менеджери надають перевагу формальним лексиці та граматиці. Працівники зазвичай надсилають неформальні повідомлення, використовуючи абревіатури, фразові дієслова та ідіоми. Ступінь їх формальності залежить від змісту документів.

Контракти укладаються для врегулювання співпраці між корпорацією та підрядниками. В них описані всі рішення стосовно фінансових витрат, термінів виконання, зобов' язань і потенційних фінансових штрафів у випадку затримок. Угоди - це юридичні документи, які приймаються місцевими органами влади на підставі законодавств європейських країн та законодавства Євросоюзу.

Обговорення є джерелом ресурсів дискурсу, що створює колективну ідентичність, результатом чого $є$ ефективна співпраця. Менеджмент як в самих організаціях, так і між організаціями $\epsilon$ певною мірою риторичним, iз застосуванням специфічного словникового складу, стратегій переконання, метафор та викладу матеріалу. 
Розглянемо, наприклад, метафори, які менеджери застосовують для настанови свого штату співробітників. Так, звичними можуть виявитися фрази на кшталт the staff members are not buying what the manager had to say чи the manager delivered a good message. Таким чином застосовується механічний формат передачі інформації, при якому учасники дискурсу розглядаються як деталі механізму організації, що можуть бути замінені. Цей механічний підхід відображений в дискурсі та метафорах, які переважно вживаються в класичному менеджменті. Так, дискурс менеджменту відображує й закріплює владні стосунки за допомогою термінів, що використовуються головним менеджером як інженером, котрий ремонтує технічні засоби, попереджуючи перебої в роботі техніки. Прикладами типових класичних метафор є: a well-oiled machine, a smoothly running operation, a spoke in the wheel, a management toolbox.

Іншими прикладами метафор, які застосовуються в діловому дискурсі (у текстах прес-релізів), є: the EU ship was heavily taking on water long before the Brexit vote (корабель Свросоюзу набирав води ще задовго до голосування no Brexit); to give politicians a sharp poke in the eye (різко штрикнути політиків чимось гострим, щьо є неприємним); winter months begin to bite the consumer (зимові місяці починають «кусати» спожсивача/ дошкуляти).

Метафори, які застосовуються в роботі з персоналом, відображують важливість командної роботи при досягненні цілей організації, наприклад: organizational goals, coaches, teams, team spirit, team effort, team work.

В 1990-х роках почали застосовуватися культурні метафори як новий спосіб розуміння й управління організаціями. Такий дискурс відображує важливу відмінність між членами організацій і тими, хто до них не належить. Us та them застосовуються по відношенню до цих категорій учасників процесу бізнесу для позначення відмінностей між конкуруючими організаціями, культурами чи професійними субкультурами. Прямі прояви управлінського впливу на рівні дискурсу дещо нівелюються, оскільки учасники цих субкультур ідентифікуються швидше завдяки ритуалам та обрядам, які мають невербальне вираження з боку управлінських структур.

Це вимагає застосування специфічних мовних засобів - професійного мовлення, а в певних ситуаціях і секретного коду, до якого можна віднести професійний жаргон і сленг.

Аналіз текстів прес-релізів компанії McLaren, наприклад, виявив низку термінів, для яких характерна яскрава образність, завдяки чому їх можна віднести до професійного жаргону, наприклад hedge fund (приватний, необмежений нормативним регулюванням фонд), Dead Cat Bounce («стрибок дохлої кішки» - різкий підйом цін акцій після тривалого падіння), to time the market (передбачати коливання на ринку), stagflation (стагфляція економічний застій при одночасній інфляціï), monetary stimulus (фінансове стимулювання). Прикладами застосування професійного сленгу у текстах 
прес-релізів є bucks та the US greenback, які застосовуються для позначення американських грошових одиниць.

Використання такого лексичного матеріалу $є$ не випадковим: воно робить його більш зрозумілим тому колу читачів, якому призначений певний текст, більш інтенційно спрямованим, а відтак - більш функціональним.

На думку Дж. Голмс, “метою соціолінгвіста є розроблення теорії, яка забезпечить мотивовану оцінку того, як мова використовується в певній спільноті, і вибору, який робиться особистостями при використанні мови" $[19$, c.16]. Н. Хомський, цитуючи Ф. Жакоба, зауважує, що “важливість мови, яка робить ii унікальною, полягає не так у ii ролі в комунікативних настановах до діï”, як “у іiі ролі у процесі символізації, у породженні когнітивних образів" [10,c.506]. Очевидно, що такі когнітивні образи виникають або спеціально створюються залежно від сфери спілкування та мети спілкування, які є ознаками мовленнєвих ситуацій.

\section{Висновки 3 дослідження.}

Мовленнєві ситуації як одиниці комунікативної компетенції характеризуються такими особливостями, як місце спілкування; особистісні властивості й характер взаємин між учасниками спілкування; мотиви спілкування; мовленнєві наміри (інтенції); сфери спілкування; теми спілкування. Мовленнєві ситуації представлені комунікативними подіями, до складу яких входять комунікативні акти.

Діловий дискурс представлений економічним дискурсом та бізнесдискурсом, між якими можна помітити певний зв'язок. При цьому бізнесдискурс можна розглядати як професійно-орієнтовану мову, а економічний дискурс - як академічний код.

Особливостями мовленнєвих або комунікативних ситуацій ділового мовлення можна вважати віднесеність їх до економічного або до бізнесдискурсу; інтенціональність комунікантів, зацікавленість їх не стільки в комунікації, скільки в досягненні певного комунікативного наміру, що досягається завдяки створенню конкретних когнітивних образів 3 використанням певних мовних засобів, а саме - професійного мовлення, яке здійснюється під час обговорення й опосередковано - у формі текстових документів залежно від мети й наміру комунікації. Професійне мовлення в комунікативних ситуаціях бізнес-дискурсу характеризується професійною термінологією, професійним жаргоном, професійним сленгом, застосуванням кліше, метафор в різних видах текстів.

Перспективи наступних досліджень вбачаємо у визначенні особливостей професійного мовлення в комунікативних ситуаціях ділового дискурсу. 


\section{ЛIТЕРАТУРА}

1. Авронин В. Проблемы изучения функииональной стороны языка: К вопросу о предмете соииолингвистики. Л.: Наука, 1975.

2. Дридзе Т. Социальная коммуникация как текстовая деятельность в семиосоциопсихологии//Общественные науки и современность 3 (1996): 145-152.

3. Карасик В. Религиозный дискурс//Языковая личность: проблемы лингвокультурологии и функичинальной семантики. (1999): 5-19.

4. Карасик В. Языковой круг: личность, концепты, дискурс. Волгоград: Перемена, 2002.

5. Караулов Ю. От грамматики текста к когнитивной теории дискурса: Вступительная статья к книге Ван Дейк, Т.A.// Язык. Познание. Коммуникаиия. М.: Прогресс. (1989): 5 - 11.

6. Тарасова Е. Речевая системность и контекст// Мовна компетениія, креативність та актуальні проблеми викладання іноземних мов. Харків: Константа. (1998): 168-175.

7. Ущина В. Позииіювання суб'єкта в сучасному англомовному дискурсі ризику. 2016. Київ: Київ. нац. лінгвіст. ун-т.

8. Формановская Н. Комуникативно-прагматические аспекты единич общения. М.: Институт русского языка им. А. С. Пушкина, 1998.

9. Хаймс Делл Х. Два типа лингвистической относительности//Новое $в$ лингвистике 7 (1975): 18-37.

10.Хомський Ноам. Антологія сучасної філософії науки, або усмішка ASIMO = Anthology of Contemporary Philosophy of Science, or ASIMO smile// Три чинники формування мови. Львів: ЛНУ імені Івана Франка, 2017. 501-548.

11.Шевченко I. Дискурс як когнітивно-комунікативний феномен// Проблеми типологї̈ дискурсу. Ред. І. С Шевченко. Харків: Костанта, 2005. 233-236.

12.Шейгал Е. Семиотика политического дискурса. Волгоград: Перемена, 2000.

13.Bargiela-Chiappini, Francesca, and Catherine Nickerson. Writing Business: Genres, Media and Discourses. Harlow, UK: Longman, 1999.

14.Bargiela-Chiappini, Francesca, Catherine Nickerson, and Brigitte Planken. Business Discourse. 2nd ed. London: Palgrave Macmillan, 2013.

15.Dudley-Evans, Tony, and Maggie Jo Saint John. Developments in English for Specific Purposes. A Multi-Disciplinary Approach. Cambridge: CUP, 1998.

16. Gimenez Moreno R. Words for Working: Professional and Academic English for International Business and Economics. Valencia: Universitat de Valencia, 2010. 
17.Goffman E. Forms of talk. Philadelphia, PA: University op Pennsylvania, 1981.

18. Habermas J. The Theory of Communicative Action (Vol. 1, Reason and the Rationalization of Society). Boston, MA: Beacon Press; 1984.

19. Holmes J. An Introduction to Sociolinguistics. Pearson Longman; 2008.

20. Salville-Troike M. The Ethnography of Communication: An Introduction. New York: Basil Blackwell, 1989.

21. Searle J. R. Speech Acts. Cambridge: Cambridge University Press, 1969.

22. Searle John Rogers. Expression and Meaning. Cambridge: Cambridge University Press; 1979. 